\title{
Perceived Service Quality and Customers Repeated Purchase Intentions in Cameroon Restaurants.
}

\author{
Diangha Sylvanus Ngoata $(\mathrm{PhD})^{1}$ \\ Department of Management University of Yaoundé II, Cameroon \\ Fokam Jeff Astein Mbah $(\mathrm{PhD})^{2}$ \\ Department of Management University of Yaoundé II, Cameroon \\ Chin Cynthia Suiven ${ }^{3}$ \\ Department of Management, University of Yaoundé II, Cameroon \\ Yayi Ngwe Philomena Urich ${ }^{4}$ \\ Department of Management, University of Yaoundé II, Cameroon \\ *Email.sdianghasylvanus@gmail.com
}

\begin{abstract}
The purpose of this study is to investigate the influence of perceived service quality on customers' repeated purchases in restaurants in the city of Yaoundé Cameroon. Data was drawn through a self-administered questionnaire distributed to a sample of 71 restaurant customers in the city of Yaoundé drawn through simple random sampling. Multiple linear regression was employed to test the study hypothesis. The study findings revealed that perceived service quality variables: Tangibles and Intangibles perceived service quality has a positive and significant influence on customers' repeated purchases in restaurants in the city of Yaoundé. By implication, restaurants operators to ensure increased customers loyalty should capitalize on, its physical evidence, employee's appearance, reliability, responsiveness, trustworthiness, and assurance of client. Nevertheless, given that clients often compare the quality of services with the price, it will be necessary to add price as a new dimension of service quality in future researches. Also, researchers should attempt to test this model in new fields and with a larger sample size to test its reliability.
\end{abstract}

Key concepts: Customer Repeated Purchase, Perceived Service Quality, Restaurant

DOI: $10.7176 / \mathrm{JMCR} / 82-07$

Publication date:November $30^{\text {th }} 2021$

\section{Introduction}

The service industry is steadily growing and is today contributing more to overall growth in Cameroon than the manufacturing industry. Addressing Customer satisfaction and expectations are critical components of any organization's long-term viability. These two strategic variables appear to be the most significant aspects that build client loyalty and desire for repeat purchases. The hospitality industry, particularly the restaurant sector, is a very competitive sector. The hospitality industry especially the restaurant sector of the industry is a highly competitive sector. In this light, attracting customers with dedicated service and high-quality food along with satisfying them and rendering them loyal is critical for the success of the business (Gilbert et al, 2004). The importance of providing quality services in restaurants has sparked a lot of interest among scholars and professionals. Quality service is typically considered to be a vital aspect in delighting consumers, generating revenue, and expanding market share 
(Ryu \& Han, 2011). Previous research has shown that delivering excellent service and food quality in a restaurant can boost customer satisfaction and loyalty.

Indeed, previous studies found that providing high service and food quality in a restaurant can enhance customer satisfaction and repeated purchase behavior directly even in an extremely bad dining experience (Ha \& Jang, 2010; Mullen \& Berry, 2007). Customers judge and rate service based on the performance of the restaurant during service delivery (Ha \& Jang, 2010). The comparisons between the expected service to be encountered with that effectively experienced by clients determines their perceptions about the service quality. In this arena, perceived service quality has a vital role in the buyer's perception of the supplier's offerings, value-added, and relationship development. Hence, a mastering of customers' service impressions is a precondition for providing the best service possible.

Bearing in mind that, when customers perceive good service and are satisfied, they typically relate their satisfaction about the brand to 9 to 10 people (informal, "word-of-mouth) (Gitomer, 1998); when they receive an inappropriate service, they usually express their discontent in the range of 15 to 20 percent each year and about $91 \%$ of the customers will not return to the store (Griffin et al, 1995), it becomes indispensable for business especially in the service sector to ensure high service quality as a based to guarantee customer satisfaction. This is very important given that improvement in customer repeated purchase by even a few percentages brings about an increase in profits by 25 percent or more (Griffin et al, 1995), while customers' dissatisfaction can lead to loss of customers which will lead to drop in profit since the cost of gaining a new customer is 10 times greater than the cost of keeping a satisfied customer (Gitomer, 1998). This caught the attention of diverse researchers on the link between customer-perceived service quality and repurchase intentions.

Although there have been several studies conducted on the impact of perceived service quality, and customers satisfaction or repurchase intentions (Cronin \& Taylor, 1994; Anderson \& Sulivan, 1993; Brown, 1993; Aydin \& Ozer, 2004; Varki \& Colgate, 2001), every minute attention has been given to this issue in restaurants and The majority of these studies focused on just one or a few specific aspects of service quality. For example, Barber et al (2011), looked at how tangible aspects affect service quality, whereas Ha \& Jang (2010) looked into how service quality influences customer satisfaction based on a few variables such as assurance, reliability, and responsiveness. Observing the restaurant sector in Cameroon, it is observed that customer is characterized by increased disloyalty as they keep on switching from one restaurant to another. At times, customers living in a hotel that has a restaurant may decide to go and buy food from a different restaurant; this, therefore, makes us examine the relationship between perceived service quality and customers' repeated purchases in restaurants. With this gap observed, it will therefore be of an added advantage to literature, to examine the combined effects of perceived tangible and intangible service quality components on customer repeated purchase intensions within a new context in Cameroon and specifically in the restaurant sectors which has been minimally approached by past studies.

This brings us to the question: To what extent does the perceived service quality influence customer's repeated purchase intention in Cameroon restaurants? More specifically, what is the influence of tangible and intangible perceived service quality on customers' repeated purchases in Cameroon restaurants? The paper's main objective is therefore to establish the link that exists between two main dimensions of perceived service quality 
tangible and intangible aspects and custom repeated purchase in the restaurant sector of the hospitality industry in the town of Yaoundé Cameroon. The rest of this study is structured as follows, in the first section, we present the literature review, in the second the methodology of research, in the third, data analysis and presentation of results, and in the last section discussion of results, general conclusion, and recommendation.

\section{Literature Review}

This subsection aims to discuss the conceptual, theoretical, and empirical literature patterning to the concept of service quality and customer repurchase intentions.

\subsection{Conceptual and Theoretical Review}

\subsubsection{The concept of service quality}

The quality-of-service concept. In the 1980 s, the first endeavor to define service quality was made, and they were based on cognitive psychology research and opined service characteristics (Churchill \& Surprenant, 1982; Hoffman, 1986). The concept of service quality has been difficult to define for researchers (Parasuraman et al., 1985). These difficulties are mainly due to the way the services were produced, consumed, and evaluated (Chelladurai, 1992). Grönroos (1984), argues that service quality is more complicated than product quality. This is due to the intangibility, transferability, perishability, heterogeneity, and non-storability nature of service that renders it difficult which makes it difficult to measure or demonstrate its quality before time to the client. This nature of service renders their marketing and sales more difficult as compared to a product whose quality can easily be measured and proven based on its tangible features such as style, color, texture, packaging (Ngambi \& Abamukong, 2020). This difficulty has led to the different conceptualization of perceived service quality. Perceived service quality, according to Grönroos (1984), is "the result of an assessment process in which clients assess their aspirations with the service they have experienced. It has also been considered as a type of attitude linked but not identical to the pleasure that arises from a comparison of expectations with perceptions and performance (Parasuraman et al., 1988). From diverse conceptualization, perceived service quality can be viewed as the image a consumer has of a firm's services based on rational analysis or evaluation of the firm's service attributes that turn to generate a positive or negative response toward this service over time.

\section{Dimension of perceived service quality}

Service quality is made up of several dimensions. Parasuraman et al, (1988), identified five main dimensions of service quality: tangibles, reliability, responsiveness, assurance, and empathy. Ahmet et al regrouped the determinants of perceived service quality into two main dimensions namely: The tangible dimension and the intangible dimension.

Tangible dimension: it represents [hysical infrastructures, personnel, technology and communication material, equipment, and service environment that serves as proof of service quality to the potential consumer of the firm's service. They are used by firms to transmit image and quality of service because they serve as the first impression to clients. In a restaurant setting, the cleanliness of the employees, the dining rooms, seat comfort, air conditions, and relaxation point are determinant tangible service quality that influences its perception. 
Intangible dimension: which regroups all the service components that cannot be touched no seen but that has an impact on consumer perception when present or absent. This dimension consists of five sub-dimensions; assurance, responsiveness, reliability, courtesy, and empathy.

Reliability: Reliability depends on handling customer service issues, performing the services right the first time; offering services on time, and maintaining a record of error-free. It is defined as the "capacity to supply the proclaimed service consistently and accurately."(Parasuraman et al, 1988). It also consists of the right order fulfillment; accuracy than commissions in service delivery and the fulfillment and maintenance of the promise of service over time. It is the most crucial component in conventional services like restaurants (Yang et al., 2004).

Responsiveness: it is "the willingness to assist clients and give timely service" (Parasuraman et al., 1988). In addition, Johnston (1997) defines responsiveness as the speed and timeliness with which services are delivered. It also includes a thorough awareness of the customer's demands and expectations, a short response time, individual attention from the employees, attention to the problem, and the customers' safety in their transactions (Kumar et, 2009). The waiting time a customer experiences to be attended to or for his command to be served in a restaurant will influence his perception of the service quality.

Assurance: it concerns the company's employee's ability to deploy their knowledge, skills, and capability to build customer trust and confidence in the firm's service. This requires an employee's disposition of adaptable competence, courtesy, security (Ngambi \& Abamukong, 2020).

Empathy: Empathy, according to Parasuraman et al. (1985), is "a caring and individual concern that the provider delivers to his clients to make them feel welcome from the moment they contact the personnel." During business hours, it entails delivering particular attention to personnel who understand the demands of their clients and customer facilities. Furthermore, to Anthonisamy et al (2011), it consists of providing individual attention and easy operation time and understanding the specific needs of customers. Empathy contains interactivity, affection, and endeavor to comprehend customer needs (Fitzsimmons \& Fitzsimmons, 2001).

Security: it entails providing safety and security of customer transactions transaction including a privacy policy. (Dabholkar, 1996) recommended adding the security dimension to future service quality research. When customers feel safe and secure dealing with a given firm, it is easy to get a repeated purchase from such a customer.

Another dimension of service quality according to the Grönroos model (1988), includes Technical quality: which describes what the consumers receive as a result of interaction with a service organization. The functional quality is that concerned with how consumers receive services. Technical and functional quality are antecedents of the corporate image - the third dimension of the model

\subsubsection{Concept of Repeated Purchase}

\section{Meaning and nature of repeated purchase}

Usually, after consumers try a product, they will end up in a situation where either their needs have been met or have failed to be met. In any case, consumers do not evaluate the product or conduct a new search and re-evaluate 
the alternative. Hellier et al (2003), defined repeated purchase intention as "defined repeated purchase intention as "a person's evaluation concerning the purchase of a designated service again from the same enterprise, in consideration of his or her present state and likely circumstances". This research defines repeated purchase intention as tourists' willingness to purchase a given restaurant brand, products, or services over and over again. It must not be confused with purchase intention, which represents a consumer's decision to purchase certain good or service in the future based on his cognitive and affective judgment of the offer compared to other alternatives. A key important indicator to evaluate customer repeated purchase behavior is customer repurchase intention (Dongjin et., 2008)

Two forms of repeated purchase intention are identified: firstly, customers intend to re-purchase products and services; and secondly, customers intention to recommend it to their friends, colleagues, or family members via positive word of mouth (Zeithaml et al., 1996). Implementing marketing strategies to seek new consumers is more costly than keeping existing consumers. That is, the cost of retaining a customer is lower than that of obtaining a new one (Shih \& Fang, 2004). Customer retention is becoming an increasingly critical challenge for companies seeking to gain a long-term competitive advantage (Dixon et al., 2005). This is in the sense that, an increase in consumers' repeated purchase intention rate leads to the company's profit, growth, reduction in marketing costs, and the consumer's willingness to pay higher premiums (Dixon et al., 2005; Magnus \& Vilgon, 1999).

\section{Determinants of repeated purchase}

Several researchers examined determinants of repurchase behavior including brand loyalty, word of mouth communication, complaining behaviors, and satisfaction or dissatisfaction (Dick \& Basu, 1994; Hellier et al., 2003). Several drivers affecting repurchase intentions were identified. They include past experiences, mood, affect, value, conveniences, service quality, customer familiarity, service failure, and recovery (Hume et al., 2007). In the specific case of restaurant four main elements are said to affect consumers repeated purchase intension namely:

Health consciousness: it refers to consumers' awareness and concern about their wellbeing and their motivation to improve, maintain a healthy life by adopting healthy behaviors and remaining connected to health issues (Newsom et al, 2005). Moreover, almost every person gives attention to issues related to nutrition and physical fitness (Kraft \& Goodell, 1993). Consumer's perception and evaluation as to whether a given food is healthy or not are some of the most primary determinants of their attitude, intention, and actual decision to purchase food products (Davies et al. 1995).

Perceived Value: the difference between the perceived benefits and costs by a consumer is known as value (Day, 1990; Leszinski \& Mam, 1997). The perceived value of a product is determined by the difference between the utility a consumer obtains from the product compared to the sacrifice made to obtain the product. In addition, four common uses of the term value have been identified namely; the low-price customer gets, whatever customer wants in a product or service, the quality customer gets for the price they pay, and what customers obtain for what they sacrifice (Parasuraman et al.,1988). 
Food Safety: it refers to the set of processes put in place to maintain the food quality by limiting its contamination and related illnesses. Food can be infected in diverse manners including; the existence of bacteria and parasites in food products, the spread of germs during the preservation or bottling process due to improper handling of the food products. Further food contamination causes include inappropriate preparation or preservation. Therefore, an individual's perception, personal experiences, attitudes towards food poisoning, perceived control over the risk of food poisoning and his character represents a major determinant of his intention to buy or repeatedly buy food from a given supplier (Henson, 1996)

Price: According to Nagle \& Holden (1995), price is a monetary value, that a consumer ascribes to a given product or service. It is what a consumer is ready to give up to obtain a given product. Consumers habitually associate a higher price with higher quality and conversely a lower price with low quality (Etgar \& Malhotra, 1981). Consumers can judge a price as convenient and be ready to purchase more if the price fits the product or service's quality. Once the utility obtains from the utilization of the product matches or exceeds the price paid, the consumer will be willing to repeat his purchase. Conversely, if the product fails to meet expectations, the client may feel that it is expensive for nothing and hence switch to alternative brands.

\section{Benefits of repeated purchase:}

Repeated purchase intention is based on satisfaction and loyalty in post-purchase actions. It has diverse advantages to a firm. firstly, it permits to reduce the cost of acquisition of new customers, secondly, it brings about increased revenue to the firms, thirdly it gives room for price premiums, and above all, it serves a competitive advantage to the firm.

\subsubsection{Theoretical Basis of Perceived Service Quality and Customer Repeated Purchase:}

Measuring service quality is difficult due to its unique characteristics: Intangibility, heterogeneity, inseparability, and perishability (Batson, 1998). In this light, Diverse theories have been developed to establish the relationship between service quality and customer pre-and post-purchase behavior. The first of this theory emerged in 1980 from the Nordic (Grönroos, 1984) and American (Parasuraman et al, 1985,1988) schools of thought. The Nordic perspective suggested two service quality dimensions - functional quality and technical quality (explained above). This gave birth to the SERVQUAL developed by Parasuraman et al $(1985,1988)$, from the gap model, and was further modified to SERVPERF which is a performance-only measure of service quality that excludes consumer expectations by (Cronin \& Taylor, 1994), who tested and proved in four industries that, in general, this model better capture and measures the deviation in service quality than the predecessor model. The SERVPERF model comprises five main service quality dimensions namely "tangibility”, "reliability”, "responsiveness", "assurance", and "empathy". In this study, we adopt the SERVPERF model to examine consumers' repeated purchase intention in restaurants within Cameroon.

\subsection{Empirical Evidence}

Diverse findings on the link between "perceived service quality" and consumers' repeated purchases have been established across the globe. Anastasia (2017), carried out a quantitative study on the expected and perceived service quality in Taiwan restaurants. According to the findings of this study, "perceived service quality" has a 
determinant effect on user satisfaction and intention to visit. also, Ramseook-Munhurrun (2012) investigated the effect of service attributes on customers' satisfaction and behavioral intentions in a Mauritius restaurant. The findings back up the connections between service quality attributes, experience, and behavioral intentions. Dehnavia et al (2014), realize a Quantitative study on the effects of "service quality" on post-purchase intention in Kerman, Iran, using structural equation modeling the study has determined that service quality, as well as perceived quality, has a positive influence on customer satisfaction and post-purchase intention.

Within the context of Cameroon, Nchendeh (2019), investigated how service quality influences customer loyalty in the Mobile Telecommunication industry in Cameroon. Within the same industry in Cameroon, Ngambi \& Abamukong (2020), findings establish through a quantitative study that, high service quality has a significant positive effect on customers satisfaction. This empirical review is indicative that the majority of the studies realize are more concerned with customer satisfaction and mostly in the developed economies. Within the context of Cameroon, those realized are within the Mobile telephony sector with virtually nothing said about the "perceived service quality" and repeated purchase in the case of restaurants. This gap is worth feeling given the observed increase in entrepreneurial attention in this sector in Cameroon with families increasingly interested in relaxation at fast food joints or restaurants. We thus attempt to feel this gap in this study.

\section{The Proposed Conceptual Model and Hypothesis development:}

The SERVPERF model (Cronin \& Taylor, 1992) is adopted as a theoretical model to examine consumers' repeated purchase intention in restaurants within Cameroon. The is justified by the fact that diverse empirical evidence has demonstrated the superiority of the model over SERVQUAL. Moreover, it fit the specific case of restaurant service evaluation as consumers are more concerned with service performance than expectations. Based on this the following conceptual model is put in place:

\section{Figure 1: The Conceptual Model}

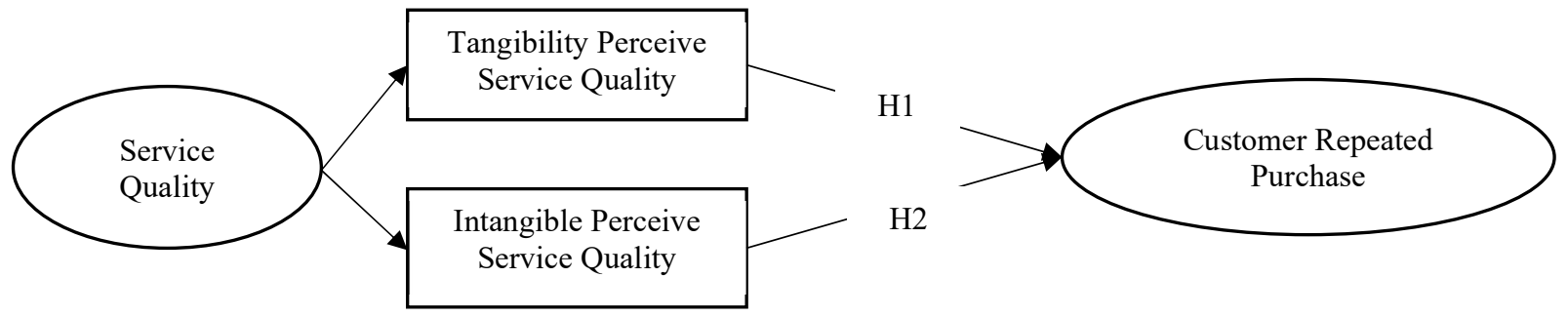

Source: Author

\section{Hypothesis development:}

\section{Tangibility and customers repeated purchase:}

As earlier stated tangibility refers to physical facilities, personnel, technology and communication material, equipment, and service environment that serves as proof of service quality to the potential consumer of the firm's service (Parasuraman et al., 1988). Al-Azzam (2015), in a study of service quality dimensions on customers 
satisfaction in the Arab bank, resulted that, tangible perceived service quality influences customers satisfaction. This finding was further supported by the studies of (Ngambi \& Abamukong, 2020; Santos, 2002; RamseookMunhurrun, 2012). Based on this we hypothesis in this study that:

\section{H1: Tangible perceive service has a positive significant effect on consumer repeated purchase intention}

\section{Intangible perceive service quality and customers repeated purchase}

Intangible perceived service regroup the set of invisible non-sortable aspects of the service system such as assurance, responsiveness, reliability, courtesy, and empathy. Dehnavia et al (2014), findings indicated a positive significant relationship between the intangible perceived service attributes and consumers' post-purchase intention. In the same light, Yang et al. (2004), findings indicated that the intangible dimensions of service are the most significant determinants of consumer repurchase intention. Base on this empirical evidence, this study hypothesizes that:

H2: Intangible perceived service quality has a positive and significant effect on consumers' purchase intention.

\section{Methodology}

\section{Model Specification.}

This study uses multiple regression analysis techniques to establish the link between service quality and customers' repeated purchases. The econometric model is specified as follows:

$Y_{i}=\beta_{1} X_{1 i}+\beta_{2} X_{2 i}+\varepsilon_{i}$

$Y_{i}=$ the explained variable "customers' repeated purchase". $X_{1 i}=$ "tangible perceived service quality" $X_{2 i}=$ "intangible perceived service quality" Here we shall have $\beta_{1}=$ the regression coefficient of $X_{1 i} \beta_{2}=$ the regression coefficient of $X_{2 i} \quad \varepsilon_{i}=$ the residue.

\section{Research Design and Approaches}

This study is quantitative and follows a hypothetico-deductive approach since hypotheses were generally formulated from a theoretical and empirical review of the literature. It is therefore situated in the positivist epistemology paradigm. A simple cross-sectional survey strategy is adopted to collect primary data used to test the study hypothesis.

\section{Operationalization of Variable and Data Collection Process}

The independent variable service quality was captured based on two main variables tangible perceived service quality (TPSQ) and intangible perceived service quality (IPSQ). The TPSQ is measured in terms of physical facilities, materials, and equipment to which two-item questions each were posed (11 item questions). The IPSQ on its part is measured in terms of Reliability, Responsiveness, Empathy, and Security, captured using two-item 
questions each (14 item questions). The independent variable repeated purchase is captured using 6 item questions that capture customers' terms of customers' satisfaction with restaurant service, intention to continuously buy the service, refer other customers to the restaurant, and positive word of mouth. A 5-point Likert scale that ranges from $1=$ strongly disagree to 5 strongly agree, was used in assessing consumers' agreement or disagreement with each of the item questions posed.

A self-administered structural questionnaire was addressed to a sample of 80 customers selected via simple random sampling in restaurants within the town of Yaoundé. This sampling technique was used to give each individual within the restaurants an equal chance of being selected. The town of Yaoundé was selected as a study area because of its cosmopolitan nature resulting from its political status as the nation's capital which attracts individuals all over the country with diverse cultural backgrounds, which could help us have a representative sample and hence generalizable results. 71 questionnaires were properly filled and returned to the researcher which gave a valid sample of 71 respondents.

\section{Data Analysis and Presentation of Findings:}

\section{Validity and reliability of the Measurement Scale}

To verify whether our scale is sufficiently reliable to be used in a questionnaire, we analyzed the psychometric qualities of this measurement instrument based on validity and reliability test. Validity was examined using "exploratory factor analysis (EFA)" and Average variance extracted (AVE) based on the Fornell-Larcker criteria. Only constructs with eigenvalues $\geq 1$ and items with factor loadings $\geq 0.5$ were retained. Reliability on its part is assessed using Cronbach Alpha (Price \& Mueller, 1986). Only factors with Cronbach alpha $\geq 0.7$ were considered as reliable. This analysis is as presented in the table below:

Table 1: Demographic Analysis of Respondents

\begin{tabular}{|l|l|l|l|}
\hline Gender & Frequency & Percentage & Cumulative Percent \\
\hline Male & 36 & 50.7 & 50,7 \\
\hline Female & 35 & 49.3 & 100,0 \\
\hline Total & 71 & 100 & 100 \\
\hline \multicolumn{4}{|c|}{ Respondent's level of education } \\
\hline Level of Edu & Frequency & Percentage & Cumulative Percent \\
\hline Primary & 2 & 2.8 & 2.8 \\
\hline Secondary & 11 & 15.5 & 18.3 \\
\hline University & 58 & 81.7 & 100 \\
\hline Total & 71 & 100 & - \\
\hline
\end{tabular}

Source: Author from Field Data 2021

It is observed that the sample gender-wise is evenly distributed as 50.7 constitute males and $49.3 \%$ female. The respondent is all relatively literates with the majority $(81.7 \%)$ respondents at the university level. 


\section{Factorial Analysis:}

Table 2: Analysis of the Reliability Test of the Variables

\begin{tabular}{|c|c|c|}
\hline \multicolumn{3}{|l|}{ Reliability statistics } \\
\hline & Cronbach's alpha & Number of items \\
\hline Tangible perceived service quality & 0.749 & 11 \\
\hline Intangible perceived service quality & 0.738 & 14 \\
\hline Customers' repeated purchase & 0.746 & 09 \\
\hline
\end{tabular}

Source: Author based on survey data

The above table indicates that the dimension used in the study were all reliable. However, not all the item questions posed were returned. The poorly loading or cross-loading items were eliminated. Just 8 item questions were valid and reliable for the test of the study hypothesis.

\section{Test of hypothesis and discussion of finding}

Table 3: The Summary Table for Tangible Perceived Service Quality

\begin{tabular}{|c|c|c|c|c|c|r|r|}
\hline \multirow{2}{*}{ Study Model } & \multicolumn{2}{|c|}{ Coefficients } & $\begin{array}{c}\text { Standard } \\
\text { deviation }\end{array}$ & $\begin{array}{c}\text { Statistics of } \\
\text { Student test } \\
(\mathrm{t})\end{array}$ & $\begin{array}{l}\text { Pearson } \\
\text { correlation (r) }\end{array}$ & $R^{2}$ & P-value (sig) \\
\cline { 2 - 6 } $\begin{array}{c}\text { TANGIBLE } \\
\text { PERCEIVED } \\
\text { SERVICE } \\
\text { QUALITY }\end{array}$ & $\beta_{1}$ & 0.925 & 0.036 & 25.542 & 0.950 & 0.903 & 0.000 \\
\hline $\begin{array}{c}\text { INTANGIBLE } \\
\text { PERCEIVED } \\
\begin{array}{c}\text { SERVICE } \\
\text { QUALITY }\end{array}\end{array}$ & $\beta_{2}$ & 0.961 & 0.037 & 26.076 & 0.952 & 0.907 & \\
\hline
\end{tabular}

Source: Author SPSS Field Data output 2021

Table 3, above indicates that in a general manner, there is a positive significant relationship between perceived service quality and customers' repeated purchases. More specifically, it indicates that both the intangible and tangible service dimension respectively has a positive significant influence on consumers' repeated purchase in restaurants within the town of Yaoundé Cameroon. This confirms our research hypotheses 1 and 2. There is therefore a strong relationship between service quality and repeated purchase. This is seen by the high correlation coefficient value.

For more clarity, and to ease managerial decision making, we subjected all the items that respected the retainment threshold of $>0.5$ for validity and 0.7 for reliability based on Cronbach's alpha to regression analysis to give a greater opportunity for decision-makers to know on what specific element of tangibility and intangibility they could capitalize to improve repeated purchase as presented in table 4 below: 
Table 4: The Analysis of Regression Model Coefficients

\begin{tabular}{|c|c|c|c|c|c|c|}
\hline \multirow[b]{2}{*}{ Dimension } & & & & & \multirow{2}{*}{$\begin{array}{l}\text { Statistics of } \\
\text { the student } \\
\text { (t) }\end{array}$} & \multirow{2}{*}{$\begin{array}{l}\text { Student } \\
\text { statistic } \\
\text { (sig) }\end{array}$} \\
\hline & $\begin{array}{l}\text { Variables } \\
\text { Extracted }\end{array}$ & Parameters & $\begin{array}{c}\text { Coefficie } \\
\text { nts }\end{array}$ & $\begin{array}{l}\text { Standard } \\
\text { deviation }\end{array}$ & & \\
\hline \multirow{3}{*}{ 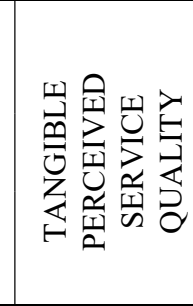 } & $\begin{array}{l}\text { The staff in the restaurant are } \\
\text { well dressed and well- } \\
\text { groomed. }\end{array}$ & $\beta$ & +0.238 & 0.168 & 1.418 & 0.161 \\
\hline & $\begin{array}{l}\text { The restaurant has up-to-date } \\
\text { equipment }\end{array}$ & $\beta$ & +0.081 & 0.195 & 0.415 & 0.679 \\
\hline & $\begin{array}{l}\text { The physical facilities of my } \\
\text { restaurant are visually } \\
\text { appealing }\end{array}$ & $\beta$ & +0.161 & 0.146 & 1.102 & 0.275 \\
\hline \multirow{5}{*}{ 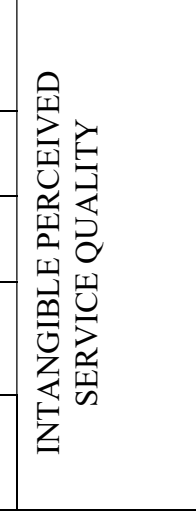 } & $\begin{array}{l}\text { The staffs in this restaurant are } \\
\text { always available to help me } \\
\text { and answer my requests. }\end{array}$ & $\beta$ & +0.342 & 0.159 & 2.150 & 0.035 \\
\hline & $\begin{array}{l}\text { The staff in this restaurant give } \\
\text { me special attention }\end{array}$ & $\beta$ & -0.094 & 0.163 & -0.579 & 0.565 \\
\hline & $\begin{array}{l}\text { The staffs in this restaurant are } \\
\text { trustworthy }\end{array}$ & $\beta$ & 0.057 & 0.174 & 0.326 & 0.745 \\
\hline & $\begin{array}{l}\text { The staffs are very quick in } \\
\text { responding to every issue I } \\
\text { face. }\end{array}$ & $\beta$ & -0.025 & 0.194 & -0.127 & 0.899 \\
\hline & $\begin{array}{l}\text { The restaurant staffs are } \\
\text { always willing to help } \\
\text { customers }\end{array}$ & $\beta$ & +0.243 & 0.151 & 1.611 & 0.112 \\
\hline
\end{tabular}

Source: Author SPSS Field Data output 2021

We see from the above table that the most important dimension of perceived service quality that influences client repeated purchase in restaurants in Yaoundé is the personnel component (dressing code and welcoming), followed by the equipment, and lastly by the physical environment. Regarding the intangible service quality, the most important aspect is employees' courtesy and assistance. Nevertheless, giving personalized service and rapidity in provision remains a major area of concern for managers to further improve client satisfaction and repeated purchase. This particular finding confirms that of Al-Azzam, (2015); Ngambi et Abamukong (2021), and Santos, (2002).

\section{Conclusion, Recommendations, and Discussion of Finding:}

The main aim of this study was to assess the influence of perceived service quality on customers' repeated purchase intentions in the hospitality sector in Cameroon. The study specifically sorted to examine the link between tangible and intangible perceived service quality and customers' repeated purchases in restaurants as a base for strategic recommendations to managers to enable them to ensure the loyalty of the currently increasing disloyal clients. This was very necessary as diverse studies in the domain have been realized but limited to other sectors like the telecommunication sector with very limited attention given to the restaurant services especially in the context of Cameroon which is on an increase. Again, most studies have examined just a single dimension or mixed up the dimension in their analysis, hence limiting specification for the managerial decision. The finding of this study indicated that both tangibility and intangibility have a positive effect on the repeated purchase. The intangible 
dimension is said to be more important in determining the client's repeated purchase. The specific dimensions of each perceived service quality and the magnitude of its effect on repeated purchase are well presented in the table

It will be judicious for managers of restaurants to capitalize on the intangible dimension of service quality to improve their client satisfaction and repeated purchase. Here they must rebuild to the dimension of employee's rapidity to service and develop a personalized means of attending to clients as means to improve their satisfaction. Insisting on the physical environment of the service provider and the employees appears like dressing codes will be a good base for building a good brand image to provoke not only repeated purchases but also positive word of mouth.

\section{Limitation of study and perspectives for future studies:}

Despite the contributed value of this study as one of the very rare studies to capture both tangible and intangible aspects of service-connected to repeated purchase intension in a rarely examine area and context of Cameroon, this study was limited just to the town of Yaoundé and made use of a limited number of respondents. Hence the finding is not perfectly generalizable. Moreover, elements such as price which has a role to play in service perception were not taken into account. Employing a study that integrates more dimensions like Price, image, economy, and with a much larger sample size using more robust analysis techniques like Structural equation modeling could be of added value to the firm. Researchers as such also try to apply this study model in another context to verify its reliability.

\section{References}

Al-Azzam, b. F. (2015). The Impact of Service Quality Dimensions on Customer Satisfaction: A Field Study of Arab Bank in Irbid City, Jordan. European Journal of Business and Management, 7(15), 45-53.

Anastasia, S. (2017). Expected and perceived service quality at "all you can eat" restaurants. Journal of Tourism, Heritage \& Services Marketing.

Anderson, E. W., \& Sulivan, M. W. (1993). "The antecedents and consequences of customer satisfaction. Marketing Science, 12 (2), 125-143.

Anthonisamy, A., Ramesh, R., \& Prabaharan, B. (2011). Service quality gap analysis in private sector bank - a customer perspective. Indian Journal of Commerce \& Management Studies, 2(1), 245-252.

Aydin, S., \& Ozer, G. (2004). The analysis of antecedents of customer loyalty in the Turkish mobile telecommunication market. European Journal of Marketing, 39(7/8), 910-925.

Barber, N., Goodman, R. J., \& Goh, B. K. (2011). Restaurant consumers repeat patronage: A service quality concern. International Journal of Hospitality Management, 30(2), 329-336.

Batson. (1998). Altruism and prosocial behavior. The handbook of social psychology. New York: McGraw-Hill.

Brown, T. C. (1993). 'Improving the measurement of service quality. Journal of Retailing, 68 (1), 127-39.

Chelladurai, P. (1992). Classification of sport and physical activity services: Implications for sports management. Journal of Sport Management, 6, 38-51. 
Churchill, G. J., \& Surprenant, C. (1982). An Investigation into the Determinants of tourism: A UK experience. Tourism Management, 27(6), 1141-1152.

Cronin, J., \& Taylor, S. (1994). SERVPERF versus SERVQUAL: Reconciling Performance-based and Perceptions-minus-expectations Measurement of Service quality. Journal of Marketing, 58(1), 125., $58(1), 125$.

Dabholkar. (1996). Consumer evaluations of new technology-based self-service options: An investigation of alternative models of service quality. Int. J. Res. Mark., 13 (1), 29-51.

Davies, B., Lockwood, A., Alcott, P., \& Pantelidis, I. (1995). Food and Beverage Management.

Day, G. (1990). Market-Driven Strategy: Processes for Creating Value: Processes for Creating Value. New York: The Free Press.

Dehnavia, P. Y., Mollahosseinib, A., \& Forghanic, M. (2014). Measuring the impact of service quality on postpurchase intention. Management Science Letters, 1837-1840.

Dehnavia, P. Y., Mollahosseinib, A., \& Forghanic, M. (2014). Measuring the impact of service quality on postpurchase intention. Management Science Letters, 1837-1840.

Dick, A. S., \& Basu, K. (1994). Customer loyalty: toward an integrated conceptual framework. Journal of the Academy of Marketing Science, 22, 99-113. doi:10.1177/0092070394222001.

Dixon, J., Evans, K. B., \& Morrison, M. (2005). An alternative perspective on relationships, loyalty, and future store choice. The International Review of Retail, Distribution and Consumer Research, 15(4), 351-374.

Dongjin, L., Shenghui, A., \& Kai, Y. (2008). Exploring Chinese consumer repurchasing intention for services: an empirical investigation. Journal of Consumer Behaviour, 7, 448-460.

Etgar, M., \& Malhotra, N. K. (1981). Determinants of price dependency: Personal and perceptual factors. Journal of Consumer Research, 217-222.

Fitzsimmons, \& Fitzsimmons. (2001). Fitzsimmons and Fitzsimmons, 2001. New York: McGraw-Hill.

Gilbert, G. R., Veloutsou, C., Goode, M. M., \& Moutinho, L. (2004). Measuring Customer Satisfaction In the industry: A cross-national approach. Journal of Services Marketing, 18(4), 371-383.

doi: $10.1108 / 08876040410548294$

Gitomer, J. (1998). Customer satisfaction is worthless, customer loyalty is priceless: How to make customers love you, keep them coming back, and tell everyone they know. Austin: Bard Press.

Griffin, Gleason, G., Preiss, R., \& Shevenaugh, D. (1995). Best practice for customer satisfaction in manufacturing firms. Sloan Management Revie.

Grönroos, C. (1984). A Service Quality Model and its Marketing Implications. European Journal of Marketing. European Journal of Marketing, 18(4), 36-44. doi: 10.1108/EUM0000000004784.

Grönroos, C. (1988). Service Quality: Six Criteria of Good Service Quality. Reviews of Business.

Ha, J., \& Jang, S. (2010). Effects of service quality and food quality: The moderating role of atmospherics in an ethnic restaurant segment. International Journal of Hospitality Management, 520-529.

Hellier, P. K., Geursen, G. M., Carr, R. A., \& Rickard, J. A. (2003). Customer repurchase intention: a general structural equation model. European Journal of Marketing, 37 (11), 1762. 
Henson, S. (1996). ConsumerwillingnesstopayforreductionsintheriskoffoodpoisoningintheUK.

JournalofAgriculturalEconomics, 47, 403-420.

Hoffman, M. L. (1986). Affect, Cognition, and Motivation. In R.M. Sorrentino \& E.T. In R. Sorrentino, \& E. T, Handbook of Motivation and Cognition (pp. 244-280). NY: Foundation of Social Behaviour.

Hume, M., Mort, G. S., \& Winzar, H. (2007). Exploring repurchase intention in a performing arts context: who comes? and why do they come back? International Journal of Nonprofit and Voluntary Sector Marketing, 12, $135-148$.

Johnston, R. (1997). Identifying the critical determinants of service quality in retail banking: importance and effect. International Journal of Bank Marketing. doi:10.1108/02652329710189366

Kumar, U., Joshi, A. K., Kumar, S., Chand, R., \& Marion. (2009). Mapping of resistance to spot blotch disease caused by Bipolaris sorokiniana in spring wheat. Theor Appl Genet, 783-792.

Leszinski, R., \& Mam, M. V. (1997). Setting Value and Not Price. The Mckinsey Quarterly, 99-115.

Magnus, S., \& Vilgon, M. (1999). Customer satisfaction and links to customer profitability: An empirical examination of the association between attitudes and behavior. SSE/EFI Working Paper Series in Business Administration, 1-21.

Mullen, E. W., \& Berry, L. L. (2007). The Combined Effects of the Physical Environment and Employee Behavior on Customer Perception of Restaurant Service Quality. Cornell Hospitality Quarterly, 48(1), 59-69. doi:10.1177/0010880406297246

Nagle, T. T., \& Holden, R. K. (1995). The Strategy and Tactics of Pricing. NJ: Prentice-Hall, Englewood Cliffs.

Nchendeh, C. (2019). Quality of Service and Customer Loyalty in Cameroon Mobile Telecommunication Service Industry. 1-68. doi:10.13140/RG.2.2.32925.15847

Newsom, J., McFarland, B. H., Kaplan, M. S., \& Huguet, N. (n.d.). The health consciousness myth: Implications of the near independence of major health behaviors in the North American population. Social Science Medicine, 60(2). doi:10.1016/j.socscimed.2004.05.015

Ngambi, M. T., \& Abamukong, A. A. (2020). The Impact of Service Quality on Customer Satisfaction in Cameroon's Mobile TelephonYy Sector. American Journal of Management, 20(4).

Parasuraman, A., Berry, L. L., \& Zeithaml, V. L. (1993). Research note: More on improving service quality measurement. Journal of Retailing, 69(1), 140-147.

Parasuraman, A., Zeitmal, V. A., \& Berry, L. L. (1988). SERVQUAL: A multiple-item scale for measuring consumer perceptions of service quality. Journal of Retailing, 64(1), 12-40.

Ramseook-Munhurrun, P. (2012). Perceived service quality in restaurant Services: evidence from the Mauritius University of Technology.

Ryu, K., \& Han, H. (2011). New or repeat customers: How does the physical environment influence their restaurant experience? International Journal of Hospitality Management, 30, 599-611. doi:10.1016/j.ijhm.2010.11.004

Santos, J. (2002). From intangibility to tangibility on service quality perceptions: a comparison study between consumers and service providers in four service industries. An International Journal, 12(5), 292-302. 
Shih, Y. Y., \& Fang, K. (2004). The use of a decomposed theory of planned behavior to study Internet banking in Taiwan. Internet Research, 14(3), 213-223. doi:doi.org/10.1108/10662240410542643

Varki, S., \& Colgate, M. (2001). The role of price perceptions in an integrated model of behavioral intentions. Journal of Service Research, 3, 232-240.

Zeithaml, V. A., Berry, L. L., \& Parasuraman, A. (1996). 'The behavioral consequences of service quality. Journal of Marketing, 60, 31-46. 